\title{
Michał Żytomirski
}

Katedra Informatologii i Bibliologii

Uniwersytet Łódzki

e-mail: michal.zytomirski@gmail.com

\section{Historia rozwoju pierwszych chińskich maszyn do pisania: od urządzeń mechanicznych do współczesnych komputerów}

\section{DOI: http://dx.doi.org/10.18778/0860-7435.22.23.07}

\begin{abstract}
Abstrakt: Głównym celem prezentowanego artykułu jest opisanie zagadnień związanych z historią, okolicznościami powstawania i sposobem funkcjonowania chińskich maszyn do pisania. W pracy pominięto kwestie związane z rozwojem pisma chińskiego, ponieważ zagadnienia z tego zakresu (w odróżnieniu od chińskich maszyn do pisania) są ogólnie dostępne w podręcznikach sinologicznych, książkach naukowych lub popularnonaukowych. W pracy zawarto informacje dotyczące dwóch chińskich maszyn do pisania: Maszyny Hou-Kun Chowa oraz Lin Yutanga. Przedstawione w artykule informacje zaczerpnięto z dokumentów patentowych oraz publikacji angielskojęzycznych. Tekst może stanowić przyczynek do szerszych badań związanych z szeroko rozumianą historią pisma.
\end{abstract}

Słowa kluczowe: chińskie maszyny do pisania, pismo chińskie w dwudziestym wieku, pismo chińskie w środowisku cyfrowym 


\section{Wstęp}

L Jedną z głównych cech ludzkich jest dążenie do ułatwiania życia poprzez, między innymi, tworzenie narzędzi, które pozwalają na usprawnienie pracy. Procesy dążenia do upraszczania i maksymalizowania wyników można zaobserwować w chęci zoptymalizowania procesu pisania - maszyna do pisania jest tego dobrym przykładem.

Chińskie maszyny do pisania są konstrukcjami dwudziestowiecznymi, które współcześnie zostały wyparte przez komputery, tablety i smartfony. Pierwsze próby stworzenia maszyn do pisania w Chinach czy Japonii były krytykowane ze względu na duży rozmiar maszyn i trudności w posługiwaniu się nimi.

Głównymi celami konstruktorów pierwszych chińskich maszyn do pisania było usprawnienie procesów pisarskich oraz ujednolicenie znaków. Maszyny do pisania miały być wykorzystywane przede wszystkim w ośrodkach administracji państwowej, gdzie szybkość i jednolitość konstruowanych przekazów ma kluczowe znaczenie.

Różnica w stopniu skomplikowania pomiędzy maszyną do pisania, która ma być użyteczna w piśmie alfabetycznym a tą, która ma być wykorzystywana w ramach tych pism, które alfabetu nie posiadają, jest diametralna. „The writing ball”, wynalazek R. Halling-Hansena, zawierał jedynie 52 przyciski (w tym 30 znaków alfabetu łacińskiego i dodatkowo angielskie znaki diakrytyczne, cyfry od 0 do 9 oraz znaki interpunkcyjne), natomiast pierwsza chińska maszyna do pisania posiadała 4 tysiące znaków.

Stworzenie maszyny, która usprawni i ujednolici pisanie po chińsku nie było zadaniem łatwym. Mnogość znaków chińskich (ok. 50 tys.) przez długi czas była bariera, która z technicznego punktu widzenia uniemożliwiała stworzenie praktycznego urządzenia.

\section{Maszyna Hou-Kun Chowa}

Pierwsza chińska maszyna do pisania została skonstruowana przez Hou-Kun Chowa, prawdopodobnie w 1915 lub 1916 r. w Chinach. Data ta nie jest dokładna, ponieważ pierwszy dokument, w którym można znaleźć wzmiankę o tym wynalazku, pochodzi z artykułu zamieszczonego na łamach „The New York Times” z 23 czerwca 1916 r. (Chinaman invents Chinese Typewriter..., 1916). Ogólnodostępne bazy danych nie uwzględniają dokumentów patentowych tej maszyny, przez co ustalenie dokładnej daty jej skonstruowania jest utrudnione.

W 1917 r. japoński wynalazca Koyota Sugimoto otrzymał w Biurze Patentów i Znaków Towarowych US patent na pierwszą maszynę, która umożliwiała pisanie w języku japońskim. Niełatwo jest stwierdzić, kto był pierwszy: 
Chow czy Sugimoto. Trudno określić, kto jako pierwszy zbudował maszynę i który z wynalazców wzorował się na swym koledze. Problematyczna jest data uzyskania patentu przez Japończyka w kraju ojczystym, ponieważ uzyskał go już w 1915 r., zaś w listopadzie 1916 r. uzyskał patent w BPiZP US. Natomiast o wynalazku Chowa pisano 23 lipca 1916 r. w „The New York Times" - nie wiadomo jednak, kiedy uzyskał licencję w Chinach. Przyjmijmy, że musiało to nastapić przed 1916 r., prawdopodobnie również w roku 1915.

Maszyna ta znacznie różniła się od swoich zachodnich odpowiedników. W Europie w tym samym czasie konstruowano już kompaktowe maszyny do pisania wspomagane elektrycznie. Dla przykładu, w 1916 r. E. Hausberg zgłosił do biura patentowego swój wynalazek sterowanej elektrycznie maszyny do pisania (Electrically-operated type-writer, 1916).

Chińska maszyna do pisania była podobna do maszyn „alfabetycznych” jedynie pod kątem zastosowania. Posiadała 4 tysiące znaków, w większości były to proste figury geometryczne, symbole proste (składowe, za pomoca których można było tworzyć znaki, nie wchodzące w zakres znaków pełnych) oraz pełne znaki, czyli takie, które samodzielnie niosą żądaną treść. Znaki najczęściej używane były ulokowane na środkowej części planszy, znaki rzadziej wykorzystywane umiejscowiono na zewnętrznych krawędziach. Pozwalało to na wykorzystanie języka chińskiego w dużym stopniu, tzn. na nieskrępowane brakiem znaków tworzenie pism o charakterze użytkowym czy artystycznym. Wszystkie symbole były odwzorowane na metalowych matrycach, które mieściły się na planszy o wymiarach $15 \mathrm{~cm}$ x $45 \mathrm{~cm}$ (Chinaman invents Chinese Typewriter..., 1916). Nad planszą zawieszona była „wajcha”; za jej pomoca wybierało się odpowiednia matrycę, która następnie odbijała w wybranym miejscu na karcie odpowiedni znak.

Zadaniem maszyny było usprawnienie procesu pisania poprzez jego przyspieszenie oraz ułatwienie odczytywania tworzonych komunikatów dzięki ujednoliceniu krojów danych znaków. Wybrane symbole zostały odwzorowane na podstawie znaków zawartych w słowniku Kang Shi. Wynalazek spełnił oczekiwania jedynie połowicznie, ponieważ nie przyspieszył pisania, a wręcz je spowolnił. Natomiast cel, jakim było ujednolicenie czcionek, został osiągnięty. Maszyna zyskała uznanie głównie w urzędach administracji państwowej, gdzie zrozumiałość tworzonych dokumentów ma prymarne znaczenie.

Mimo małego stopnia praktyczności nowej maszyny wynalazca dokonał przełomu: udowodnił, iż stworzenie maszyny do pisania w piśmie tak bogatym w znaki jest możliwe. 


\section{Michał Żytomirski}

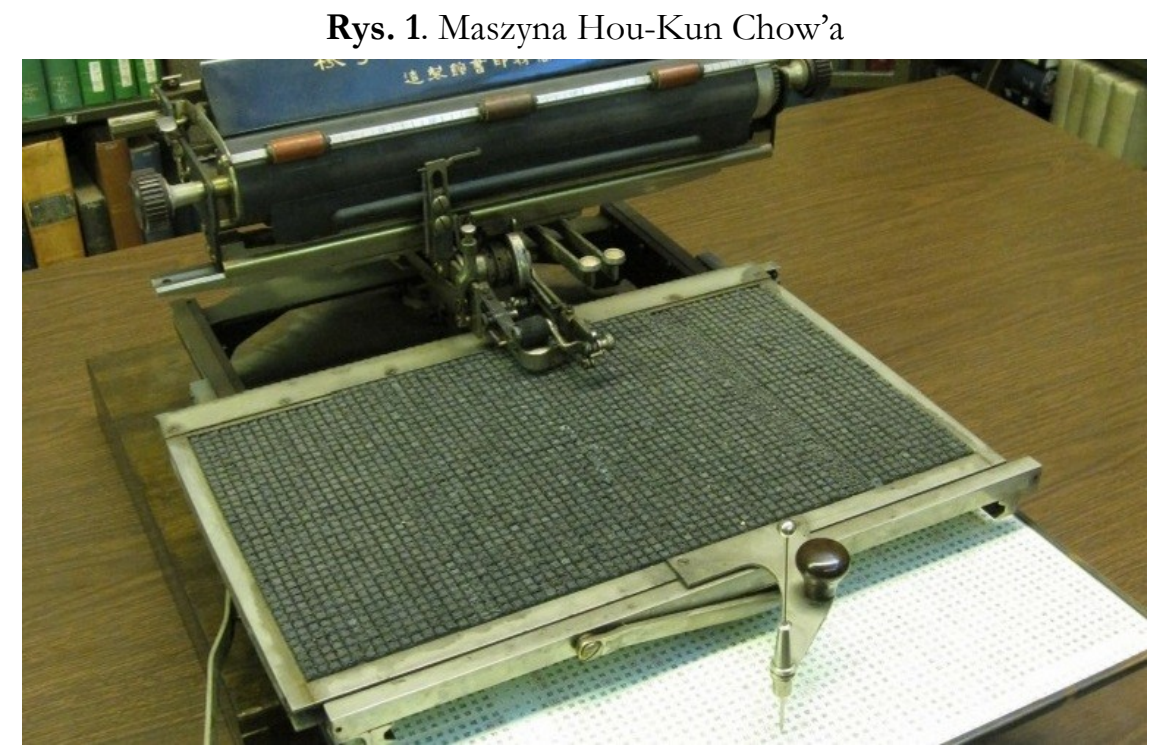

Źródto: Chinese Typewriters Exist..., 2016

\section{Maszyna Lin Yutanga}

Kolejnym krokiem w stronę usprawnienia procesu pisania było stworzenie maszyny „Ming Kwai” przez Lin Yutanga ${ }^{1}$. Celem L. Yutanga było utworzenie prostej w użyciu kompleksowej (czyli w tym przypadku takiej, która będzie uwzględniać wszystkie znaki występujące w piśmie chińskim) maszyny do pisania po chińsku. Zadanie to w czasach, gdy nie istniały komputery, wydawać się mogło niemożliwe, ponieważ taka konstrukcja musiałaby umożliwić tworzenie około 50 tysięcy znaków.

Poprzednicy dr. L. Yutanga w zakresie tworzenia chińskich maszyn do pisania postawili na umieszczanie na planszy matryc, które miały w jak największym stopniu pokrywać się z zakresem znaków w piśmie chińskim. Wspomniana wcześniej maszyna K. H. Chowa posiadała około 4 tysięcy matryc, które pozwalały na zapisanie dziesiątek tysięcy znaków. Skutkowało to „rozrośnięciem” się owych plansz do sporych rozmiarów, co bardzo spowalniało korzystanie z nich i utrudniało ich przenoszenie.

\footnotetext{
${ }^{1}$ Lin Yutang, chiński pisarz i wynalazca urodzony w 1885 r. w mieście Xiamen (prowincja Fujian) uzyskał tytuł bakałarza, odpowiednik znanego w Polsce licencjatu, na Uniwersytecie św. Jana w Szanghaju. Następnie studiował na Uniwersytecie Harwardzkim, studiów tych jednak nie dokończył, ponieważ wyjechał do Francji, a następnie do Niemiec. W Lipsku uzyskał stopień doktora z zakresu sinologii. Po powrocie do Chin wykładał literaturę angielską na Uniwersytecie Pekińskim.
} 
L. Yutang, chcąc jak najbardziej zmniejszyć rozmiary maszyny, jednocześnie nie tracąc na jej możliwościach do zapisywania tysięcy znaków, postanowił oprzeć cały jej mechanizm na ośmiu ruchomych cylindrach gęsto wypełnionych znakami².

Rys. 2. Szkic patentowy maszyny „Ming Kwai”

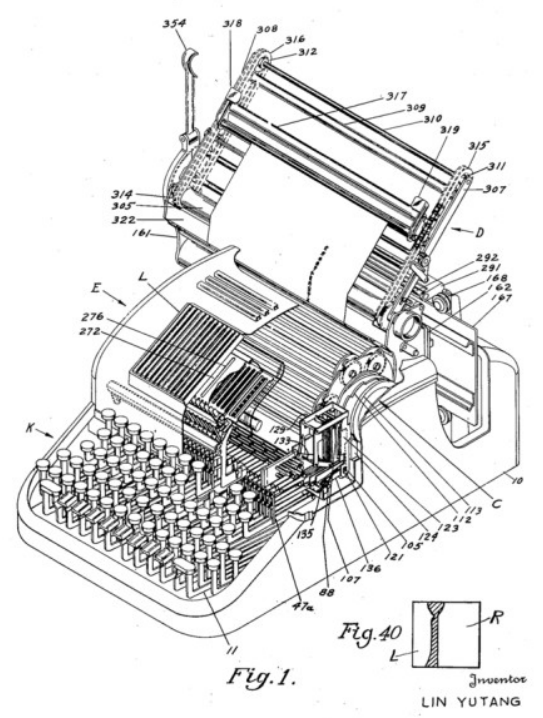

Źródto: Google Patents (http:/www.google.com/patents/us2613795)

Dr L. Yutang uzyskał patent na swoją maszynę w Biurze Patentów i Znaków Towarowych 17 kwietnia 1946 r. (patent nr: 2613795) (Chinese Typewriter: Patent..., 1946).

Wynalazca pracował nad stworzeniem swojej maszyny około 30 lat. Koszt projektu wyniósł w przybliżeniu 120 tys. dolarów amerykańskich (Williams, 2010). Jego maszyna była o wiele mniejsza od maszyny H. K. Chowa, mierzyla 36x46x23 cm (por. Chinese Typerwiter: Patent..., dz. cyt.); warto zauważyć, że rozmiar ten nie był wiele większy od wymiarów maszyn popularnych w tym czasie na Zachodzie. W magazynie „Mechanix Illustrated” z listopada 1947 r. można przeczytać, iż Ming Kwai posiadała 72 klawisze, w tym 64 klawisze służyły do wybierania znaków, 8 klawiszy służyło do wybierania kombinacji z odpowiedniego cylindra (New Typewriter conquers..., 1947). Z tego samego źródła wiemy, iż maszyna posiadała 6 cylindrów, każdy z nich

\footnotetext{
2 Prawdopodobnie, Lin Yutang projektując swoją maszynę wzorował się na osiagnięciu Chung-Kin Kao, który w 1944 roku opatentował swoją maszynę do pisania. Maszyna ta umożliwiała zapisanie 6000 znaków pisma chińskiego.
} 


\section{Michał Żytomirski}

dysponował 7 tys. kompletnych znaków chińskich oraz 1,4 tys. komponentów, czyli składowych (tamże). Obliczono, że maszyna Ming Kwai umożliwiała stworzenie ok. 90 tys. znaków, co umożliwiło całościowe objęcie znaków chińskich, ponadto pozwalała na tworzenie nowych słów (prawdopodobnie dzięki tej maszynie moglibyśmy współcześnie zapisać po chińsku słowo np. „grafen” oraz inne słowa, o których konstruktor maszyny nie mógł mieć pojęcia).

Pisanie na Ming Kwai wymaga od użytkownika pewnej praktyki. Proces uczenia się w tym przypadku nie jest aż tak długi, jak w przypadku maszyny H. K. Chowa. Według artykułu z „Mechanix Illustrated” wystarczy jedynie parę minut, aby biegle opanować pisanie na Ming Kwai. Od użytkownika wymagana jest „tylko” znajomość znaków, resztę „podpowiada” mechanizm. Maszynę wyposażono w tak zwane „magiczne oko”, przez które użytkownik zaglądał do wnętrza Ming Kwai, gdzie umieszczone były heksagonalne cylindry z wielką liczbą symboli. Co ciekawe, przez szybkę „magicznego oka” pisarz widział jedynie 6 kombinacji znaków, możliwych do złożenia ze znaków podstawowych, jakie wybrał przed chwila z klawiatury. Każdy symbol brany był z innego cylindra, w przypadku powielania się podobnych znaków z jednego cylindra brany pod uwagę był jedynie ten najbardziej pasujący do wybranych kształtów - znaki podobne do siebie były umiejscowione w możliwie najbliższej odległości.

Rys. 3. Maszyna Ming Kwai

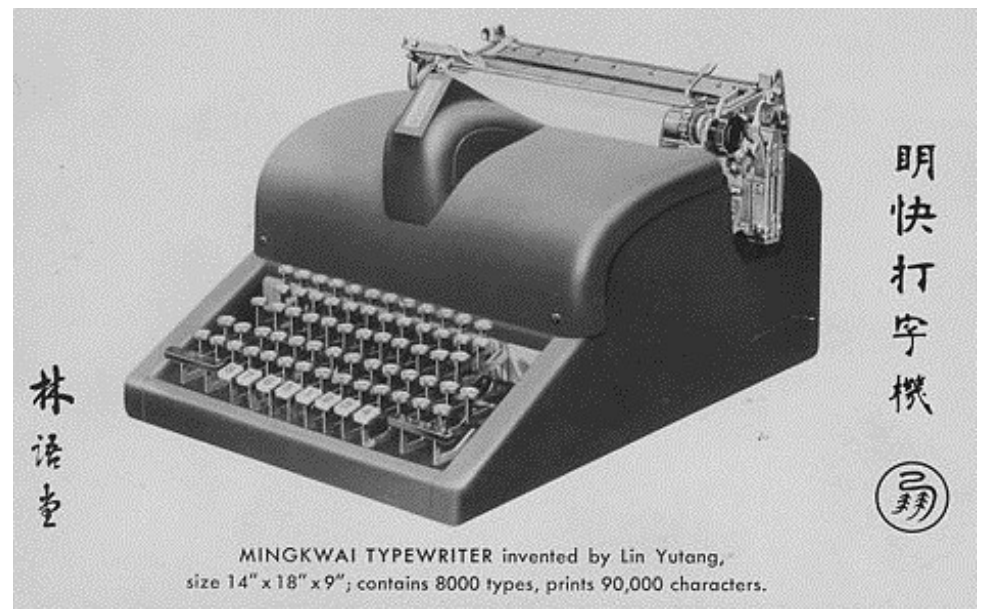

Źródto: Roses in an Iron Garden..., 2012

Jeśli pisarz nie znalazł żądanego wyrazu, mógł dopisać jeszcze jeden symbol podstawowy w celu zawężenia zakresu symboli. Praca maszyny oparta była na algorytmach (przykładowo, jeżeli pisarz wybrał znak z klawisza 1., następnie 34. i 21., to wynik logiczny zawężony był do znaku A i B - następ- 
nie pisarz wybierał ten, którego szukał). Cały mechanizm był niezwykle skomplikowany. Trudno jest opisać powiązania mechaniczne pomiędzy klawiszami a cylindrami, można się jedynie domyślać, iż każdy klawisz powinien być połączony z każdym cylindrem więcej niż jeden raz. Cylindry musiały być „powiązane" ze sobą, musiały przekręcać się według porządku, który powinien zmieniać się w zależności od tego, jaka składowa pisarz wybrał na początku, a jakie kolejno. Przy tak ogromnych możliwościach dla jednego klawisza, jednego znaku prostego, winno być przypisanych 703125 kombinacji ${ }^{3}$. Oczywiście powiązań musiało być znacznie mniej, pisarz wybierał zwykle minimum dwa znaki składowe, aby szukać odpowiedniego, co zawężało zakres możliwości. Po wciśnięciu znaku prostego maszyna nie wybijała go na karcie, chyba że zostało to potwierdzone przez klawisz odpowiedniego cylindra. Kartka papieru przewijała się automatycznie, ale mogła też być kierowana manualnie przez użytkownika.

Lin Yutang chciał, aby we wszystkich chińskich biurach używano maszyny do pisania dla usprawnienia pracy urzędników. Zamierzał stworzyć maszynę, dzięki której każdy znak chiński będzie mógł być napisany za pomocą maszyny, oraz chciał, by ludzie mieli świadomość, że może istnieć maszyna, która zdolna jest utworzyć każdy znak chiński - bez względu na to, czy ktokolwiek wykorzysta jej potencjał chociażby w 10\%. Warto wspomnieć, iż L. Yutang pod koniec lat 40. i w latach 50. XX wieku pracował nad latynizacja pisma chińskiego, nad jego transkrypcja i transliteracja na alfabet łaciński. Stworzenie Pinyin, czyli systemu latynizacji języka chińskiego, pozwoliło na pisanie po chińsku na maszynach wykorzystujących alfabet łaciński.

\section{Pismo chińskie we współczesnych komputerach}

- Obecnie, w epoce Internetu i rozwoju technologii, maszyny do pisania są urządzeniami archaicznymi. Pismo chińskie jest obecne również w komputerach, paradoksalnie proces stworzenia systemu komputerowego, który pozwala na pisanie znaków chińskich w środowisku cyfrowym, był łatwiejszy do zrealizowania niż stworzenie chińskiej maszyny do pisania.

Poszukując informacji dotyczących chińskich klawiatur komputerowych można odnaleźć wiele ich typów. Najczęściej powtarzającymi się są:

1) zmodyfikowane klawiatury QWERTY (zmodyfikowane względem europejskich standardów),

2) klawiatury typu ,monster”,

3) ekrany do pisania.

\footnotetext{
${ }^{3}$ Jeżeli występowałby w jedynie połowie możliwych znaków (64 -klawisze, znaki proste, 90 tys. możliwości / $2=45$ tys. 45000/64=703125 możliwości występowania znaku prostego na cylindrach.
} 


\section{Michał Żytomirski}

Zmodyfikowane klawiatury QWERTY działaja podobnie do znanych nam standardowych klawiatur. Posiadaja zazwyczaj znaki alfabetu łacińskiego oraz znaki poboczne, diakrytyczne, które wybierane sa poprzez wciśnięcie odpowiedniej kombinacji klawiszy - podobnie jak w przypadku polskich znaków diakrytycznych (c+alt=ć).

Jeden klawisz posiada zazwyczaj około czterech możliwości. Programy umożliwiające pisanie np. Microsoft Word w wersji chińskiej posiadaja funkcje podpowiadania znaków, działają na takiej samej zasadzie, jak podpowiadanie $\mathrm{w}$ tak zwanej autokorekcie, tzn. jeżeli popełnimy błąd ortograficzny, to dzięki tej opcji się o tym dowiemy. Aplikacje do pisania posiadaja zainstalowany zakres znaków, jakie są w stanie odtworzyć; zakresy te można powiększać poprzez instalowanie dodatków, łatek itp. Zastosowanie to daje możliwości użycia każdego znaku chińskiego, jaki został stworzony i dodany do bazy danych (działa to na tej samej zasadzie, jak działanie $>>$ wstaw-> znak specjalny ${ }^{\wedge}$ wybierz $<<$, które znane jest popularnych wersji MS Word itp.).

Klawiatury typu monster wykorzystywane są przez osoby, które twierdzą, iż standardowe klawiatury z QWERTY sa źródłem wielu pomyłek oraz nie są $\mathrm{w}$ stanie zaspokoić ich potrzeb pisarskich. Klawiatury te posiadaja więcej możliwości, zazwyczaj 12 znaków na jeden klawisz. Mechanizm wpisywania jest podobny jak w przypadku QWERTY: za dany znak odpowiada dana kombinacja klawiszy. Klawiatury typu „monster” nie są obecnie często wykorzystywane, liczne dodatki i łatki do programów pisarskich umożliwiające napisanie każdego znaku wyparły argument mówiący o ograniczeniach związanych z QWERTY.

Kolejnym ciekawym rozwiązaniem, umożliwiającym pisanie po chińsku są klawiatury lub urządzania z ekranem dotykowym. Umożliwiają one zaprogramowanie klawiatury według indywidualnych potrzeb użytkownika. Znaczy to, iż na miejscu symbolu „A” użytkownik może wstawić symbol „I”, jeśli będzie tego potrzebował. Wirtualne klawiatury dają często możliwość pisania po nich specjalnym rysikiem, utworzony znak jest odczytywany przez system, a następnie zapisywany w przyjętej formie w dokumencie (tzn. jeśli użytkownik napisałby ręcznie na ekranie mało zgrabną literę A, to system odczytałby wpisany znak i odwzorowałby go już w formie odpowiedniej dla danego fontu). Warto wspomnieć, że istnieja ciekawe sposoby zapisywania danych za pomocą nowych technologii, np. konwertery mowy ludzkiej, dzięki którym komputer wychwytuje poszczególne słowa, a następnie zapisuje je w formie tekstu takie rozwiązania są możliwe również w języku chińskim.

Z punktu widzenia Europejczyka używanie symboli chińskich w językach programowania może wydać się problematyczne, ale jednocześnie wytłumaczalne. Dla przykładu, jeżeli posiadamy kłódkę, która otwiera się dzięki kom- 
binacji 1-2-3, oraz kłódkę, która otwiera się dzięki kombinacji q-w-e, to czy mechanizm działania kłódki jest inny, jeśli są to te same modele? Znaki, jakie używane są w systemach, aplikacjach, programach, nie są istotne. Istotny jest schemat, kod, w jakim system odczytuje znaki. Jeśli zaprogramujemy dana aplikację tak, aby reagowała na dane symbole, to w środowisku cyfrowym nie jest ważne, jaki język zastosujemy. Znaczy to, że znaki chińskie wykorzystywane są w takim samym stopniu w systemach, programach itp.

W środowiskach cyfrowych zazwyczaj używa się języków sztucznych, często cyfrowych, nie muszą być one oparte na alfabecie. Najczęściej jednak specjalistyczne języki programujące opieraja się na języku angielskim, z cała pewnościa jest on wykorzystywany również przez chińskich informatyków.

\section{Zakończenie}

L Proces tworzenia maszyn do pisania w Chinach był procesem wtórnym względem procesu tworzenia maszyn piszących konstruowanych w Europie. Celem konstruktorów zarówno w pierwszym, jak i drugim przypadku, było usprawnienie procesu pisania i ujednolicenie znaków po to, aby zniwelować pomyłki i ewentualne problemy z odczytaniem treści (problemy te moga być obecne w piśmie ręcznym, głównie w przypadku nieczytelnego charakteru pisma autora treści).

Przeszkody, z jakimi zmagali się konstruktorzy europejscy, były znacznie prostsze do pokonania niż te, z którymi borykali się konstruktorzy chińscy. Głównym założeniem maszyny do pisania jest umożliwienie zapisu wszystkich słów języka - w przypadku języków, które wykorzystuja alfabet, należy uwzględnić wszystkie części składowe występujące w danym języku (litery), w przypadku języka, który alfabetu nie posiada, należałoby uwzględnić wszystkie słowa/znaki/symbole tworzące ten język.

$\mathrm{Na}$ zakończenie warto zaznaczyć fakt, że pismo chińskie zawiera około 50 tys. znaków, a podstawowy alfabet łaciński liczy ich 26. Tak jak wspomniano powyżej, chińskie maszyny były wzorowane na maszynach wykorzystywanych w Europie czy USA, natomiast w ostatecznym wyniku konstrukcje chińskie i zachodnie łączyła jedynie idea oraz wybijanie znaków na papierze, natomiast mechanizmy i ich sposób działania były nieporównywalnie inne na tej podstawie można wysnuć wniosek, że chińskie maszyny do pisania stanowią odrębną dziedzinę w zakresie szeroko rozumianej historii pisma. 


\title{
Bibliografia
}

Chinaman invents Chinese Typewriter using 4,000 characters. (1916). The New York Times, July 23. Pobrane 16 kwietnia 2016, z: http://query.nytimes.com/ $\mathrm{mem} /$ archive-free/pdf?res=9503E0D8153BE233A25750C2A9619C946796D6CF

Chinese Typewriter: Patent US2613795. (1952). Google Patents. Pobrane 21 kwietnia 2016, z: https:/ /www.google.com/patents/US2613795?dq=2613795\&hl=pl\&sa $=$ X\&ei=luIWVZf XAoKpyQPn-4CoDA\&ved=0CB8Q6wEwAA

Chinese Typewriters Exist, and Tom Mullaney Wants to Save Them. (2016). South China Morning Post. Edition Hong Kong. HK Magazine. 13 July. Pobrane 20 sierpnia 2016, z: http://www.scmp.com/magazines/hk-magazine/article/2038079/ chinese-typewriters-exist-and-tom-mullaney-wants-save-them.

Electrically-operated type-writer: Patent US1200105A. (1916). Google Patents. Pobrane 21 kwietnia 2016, z: https://www.google.com/patents/US1200105?dq $=\mathrm{US}+1200105+\mathrm{A} \& \mathrm{hl}=\mathrm{pl} \& \mathrm{sa}=\mathrm{X} \& \mathrm{ved}=0 \mathrm{ahUKEwjo1v39q6jQAhUCXCwKHc}$ b9AiEQ6AEIHTAA

New Typewriter conquers Chinese symbols. (1947). Mechanix Illustrated, 11, 137. Pobrane 20 kwietnia 2016, z: http://blog.modernmechanix.com/new-typewriterconquers-chinese-symbols /

Roses in an Iron Garden: Random, Solitary Thoughts on Typewriters. (2012). Oz'Typewriter: the wonderful world of typewriters. Pobrane 20 kwietnia 2016, z: http:/ / oztypewriter.blogspot.com/2012/07/roses-in-iron-garden-randomsolitary.html

Williams, R. John. (2010). The Technê Whim: Lin Yutang and the Invention of the Chinese Typewriter. American Literature, 82(2), 389-419. Pobrane 20 kwietnia 2016, z: https://rjohnwilliams.files.wordpress.com/2010/05/williams-americanliterature-82-21.pdf

\section{The history of the development of China's first typewriters: from me- chanical devices to modern computers}

\begin{abstract}
The main purpose of this article is to describe issues related to history, the circumstances of the formation and the functioning of the Chinese typewriter. The study omitted the issues related to the development of Chinese writing, because the issues in this area (in contrast to the Chinese typewriters) are generally available in sinology textbooks, scientific or popular books. The study contains information on the two Chinese typewriters: Machines created by Hou-Kun Chow and Lin Yutang. The information in the article were taken from the patent documents and English-language publications.
\end{abstract}

KEYWORDS: Chinese typewriter, Chinese writing in the twentieth century, Chinese writing in the digital environment 